\title{
Ethanolic extract of black grapes (Vitis Vinifera) ameliorates overtraining- induced pancreatic $\beta$-cells and muscle damage
}

\author{
Ferbian Milas Siswanto ${ }^{*}$, Risha Catra Pradhany ${ }^{2}$, Boedi Prihatini Yenniastoeti ${ }^{3}$, and \\ Alex Pangkahila 4
}

'Department of Biology, Faculty of Health, Science, and Technology, Dhyana Pura University, Badung, Indonesia

${ }^{2}$ Veterinary Medicine, Faculty of Medicine, Hasanuddin University, Makassar, Indonesia

${ }^{3}$ Postgraduate Program on Anti Aging Medicine, Faculty of Medicine, Udayana University,

Denpasar, Indonesia

${ }^{4}$ Department of Andrology and Sexology, Faculty of Medicine, Udayana University,

Denpasar, Indonesia

*Phone: +818025163415, E-mail : ferbianms@undhirabali.ac.id

*Corresponding author: Ferbian Milas Siswanto

(ferbianms@undhirabali.ac.id)

\begin{abstract}
Overtraining is a high-volume, high-intensity, long-duration, and high-frequency training. Increasing physical training burden followed by oxygen demand required for aerobic metabolism. Increasing oxygen usage causes an elevation of electron leakage in mitochondria; thus, produce a higher amount of reactive oxygen species (ROS). Antioxidant inhibits oxidative damage in a target molecule. Grapes contain a lot of antioxidants, such as polyphenols and anthocyanins. The purpose of this study was to examine the effect of ethanol extract of Balinese grapes (Vitis vinifera) on b-cells and muscle damage in overtraining-induced rats. This study was a completely randomized experimental study using a posttest only control group design. Samples were 36 male albino rats (Rattus norvergicus), aged 2.5-3 months, divided randomly into two groups. The control group (PO), 18 rats, were given overtraining and placebo of $2 \mathrm{ml}$ distilled water; the treatment group (P1), 18 rats, were given overtraining and $25 \mathrm{~g} / \mathrm{kg} . \mathrm{BW}$ ethanol extract of Balinese grapes. The result showed the number of pancreatic b-cells in the P1 group was significantly higher than the PO group $(p<0.001)$. In contrast, the average level of total creatine kinase was significantly lower in the Pl group than those of the PO group $(p<0,001)$. It can be concluded that the administration of ethanolic extract of Balinese grapes mitigates the damage on pancreatic $b$-cells and muscle cells induced with overtraining.
\end{abstract}

Keywords: Balinese grapes, pancreatic 8 cells, total creatine kinase, overtraining.

Copyright @ 2020 JRVI. All rights reserved.

\section{Introduction}

Physical activity has been widely known to inhibit the aging process (Haryanto, Pangkahila, Aman, \& Siswanto, 2019; Siswanto \& Pangkahila, 2014; Zenitalia, Pangkahila, Pangkahila, \& Siswanto, 2018). However, the lack of physical activity or excessive physical activity will cause 
a hormonal imbalance that causes cell damage, leading to a premature aging process (Kartiko \& Siswanto, 2015; Siswanto \& Pangkahila, 2015). Research showed that regular exercise can reduce the risk of death by $17 \%$ for every 1-metabolic equivalents of exercise capacity increase (Gulati et al., 2003). On the other hand, excessive exercise will cause adverse effects. It commonly occurs, as research on athletes who died suddenly while competing indicated that the cause of death due to excessive physical training-induced hypertrophic cardiomyopathy (Wasfy, Hutter, \& Weiner, 2016). Many studies show that excessive physical training can lead to oxidative stress (Kartiko \& Siswanto, 2018; Nyandra, Kartiko, Arunngam, Pangkahila, \& Siswanto, 2018). This is due to increased oxygen consumption up to 100-200 times. Generally, $2-5 \%$ of the oxygen used in metabolic processes will become superoxide ions, so that heavy physical activity increased production of free radicals that would trigger oxidative stress and eventually damage a lot of cells in the body (Pangkahila, Linawati, Sugiritama, \& Siswanto, 2019), including pancreatic $\beta$-cells (Siswanto, Yenniastuti, Putra, \& Kardena, 2015) and skeletal muscle cells (Pereira et al., 2013).

The levels of the creatine kinase in serum is a potential marker to determine the functional status of muscle tissue. Increased serum level of creatine kinase describes cellular necrosis index and damage of muscle tissue both in an acute or chronic injury. Changes in muscle enzyme levels can also be found in normal subjects and in athletes after strenuous training. The creatine kinase (CK) is a typical enzyme found in muscle (Baird, Graham, Baker, \& Bickerstaff, 2012). In order to prevent oxidative stress-related pathology, the administration of antioxidants is necessary. A well known non-enzymatic antioxidant is a flavonoid that acts as a free radicals chain-breaking (Nimse \& Pal, 2015). The grape (Vitis vinifera) peel and seed abundantly contain flavonoids (Doshi, Adsule, Banerjee, \& Oulkar, 2015). It also contains anthocyanins, which are antioxidants that have a high potential as a free radical scavenger and is protective against oxidative stress, and also inhibit lipid peroxidation in the body (Khoo, Azlan, Tang, \& Lim, 2017). The grape seed extract is also known to have a strong antioxidant action, especially the content of proanthocyanidins which have a better antioxidant property compared to vitamin $C$, vitamin $E$ and $\beta$-carotene in protecting cells from DNA damage and lipid peroxidation due to free radical (Yang et al., 2018).

Despite the well-established antioxidant content of grape, a study on its effect to ameliorate overtraining-induced pathology is limited. Hence, we aimed to examine the effect of ethanol extract of Balinese grapes (Vitis vinifera) on $\beta$-cells and muscle damage in overtraining-induced rats.

\section{Materials and Methods}

This study was true experimental research using a completely randomized posttest only control group design. The samples were male albino rats (Rattus norvegicus), wistar strain, aged 2.5-3 months, with around 180-200 grams weight. The number of samples was 18 rats/group, therefore a total of 36 rats were used.

Rats were adapted for a week and were divided into two groups: The control group (P0), 18 rats, were given overtraining and placebo of $2 \mathrm{ml}$ distilled water; the treatment group (P1) 18 rats, were given overtraining and $25 \mathrm{~g} / \mathrm{kg}$. BW ethanol extract of Balinese grapes. The Balinese grapes extract was prepared according to the previously described method (Widhiantara, Arunngam, \& Siswanto, 2018). In summary, the dried whole-fruit was coarsely powdered using a grinder and then extracted with $95 \%$ ethanol in the Soxhlet apparatus, filtered by Whatman paper and the solvent was dried by vacuum rotary evaporator at $50^{\circ} \mathrm{C}$. 
After 14 days of treatment, blood sample was drawn through medial canthus sinus orbitalis for the total creatine kinase levels measurement. The rats were then euthanized to collect the pancreas for pancreatic $\beta$-cells examination. The pancreas of each animal was sliced in the size of about $1 \times 1 \times 1 \mathrm{~cm}^{3}$ and immersed in a fixative solution of $10 \%$ neutral buffered formalin, prior to further processing for histopathological preparations.

Serum creatine kinase levels were measured by Creatine Kinase (CK) Colorimetric Assay Kit (BioVision, San Francisco, CA, USA) according to the manufacturer's instruction that has been described previously (Han, Wu, \& Wang, 2019). The method in tissue preparations for histopathology were adapted from Kiernan's method as described previously (Widhiantara et al., 2018). Gomori Chrome Hematoxylin Phloxine B-Staining staining was used in this study (Siswanto et al., 2015).

The data were analyzed statistically using the Statistical Package for Social Sciences (SPSS) version 22.0. Data analysis was performed using an independent sample $T$-test.

\section{Results and Discussion}

\section{Pancreatic 6-Cells Count}

Pancreatic $\beta$-cells stained by Gomori Chrome Phloxine Hematoxylin B-Staining will appear brown, pancreatic $\alpha$ cells will appear red, and pancreatic $\delta$ cells will be pink (Figure 1). The mean of pancreatic $\beta$-cells count of the P1 group was significantly higher than those observed in $\mathrm{PO}$ group (43.63 \pm 7.74 vs $30.00 \pm 3.56, \mathrm{p}<0,001)$ (Table 1).

\section{A}

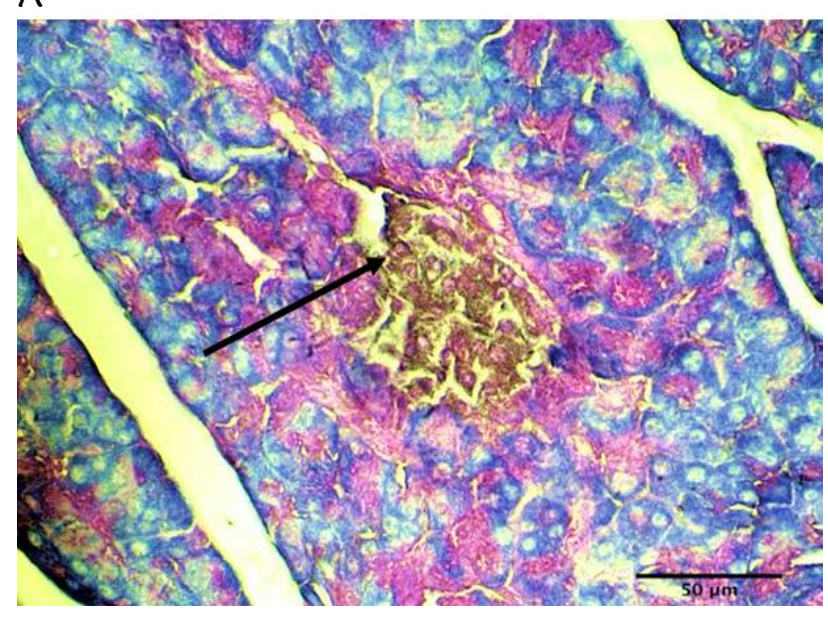

B

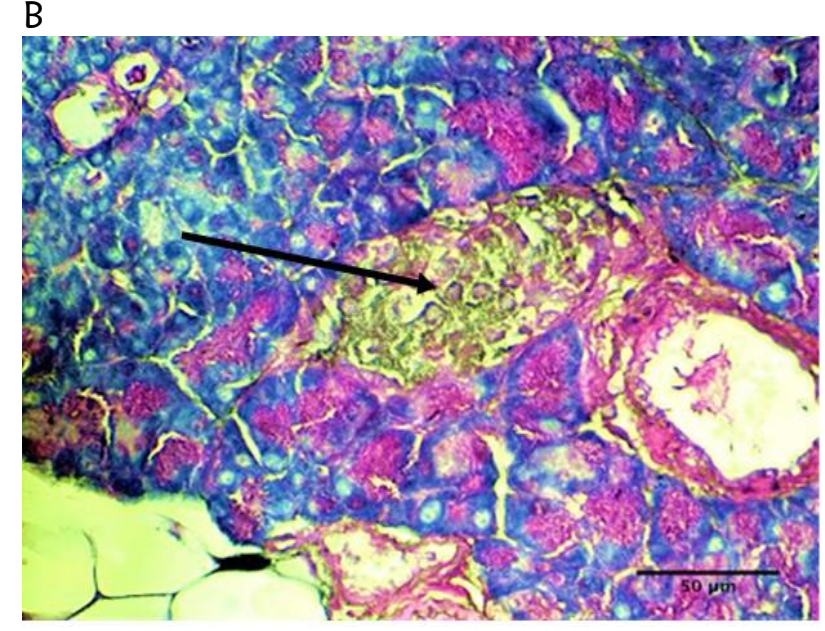

Fig 1. Histopathological examination of the Langerhans of Pancreatic Tissue. (A) Control Group (PO), and (B) Treatment Group (P1). Arrows show a single pancreatic $\beta$-cells. Stained with Gomori Chrome Phloxine Hematoxylin B-Staining, 400 times magnification.

The results of this study showed that the ethanol extract of Balinese grapes can prevent a decrease in the number of pancreatic $\beta$-cells induced by excessive physical training. In this study, rats were swum until almost drowned in order to obtain conditions of oxidative stress (Siswanto et al., 2015). During overtraining, increased oxygen supply are often unable to meet the oxygen demand. The sudden supply of high oxygen will increase the formation of oxygen free radicals could even achieve 10 times, which was called as reperfusion (González-Montero, Brito, Gajardo, \& Rodrigo, 2018). 
Table 1. Pancreatic $\beta$-Cells Count and Total Creatine Kinase level Comparison

\begin{tabular}{lllllcc}
\hline \multicolumn{1}{c}{ Variables } & \multicolumn{1}{c}{ Group } & $\mathrm{N}$ & Mean & SD & $t$ & $p$-value \\
\hline $\begin{array}{l}\text { Pancreatic } \beta \text {-Cells } \\
\begin{array}{l}\text { Count (cells/field } \\
\text { of view) }\end{array}\end{array}$ & Control group (P0) & 18 & 30.00 & 3.559 & 6.40 & 0.000 \\
\hline $\begin{array}{l}\text { Total Creatine } \\
\text { Kinase level } \\
\text { (mU/mL) }\end{array}$ & Control group (P0) & 18 & 289.56 & 18.822 & 205.626 & 0.000 \\
\hline
\end{tabular}

$\mathrm{N}=$ Number of Sample; $\mathrm{SD}=$ Standard Deviation, $\mathrm{t}=\mathrm{t}$-value.

The imbalances between reactive oxygen species (ROS) and antioxidants can initiate oxidative stress, which without proper treatment, can manifest into disease. In type 1 diabetes mellitus, T-cell-mediated autoimmune destruction of pancreatic b-cells is secondary to the primary invasion of macrophages and dendritic cells (DCs) into the islets. Macrophages/DCs, however, are activated by intercellular ROS from resident pancreatic phagocytes and intracellular ROS formed after receptor-ligand interactions via redox-dependent transcription factors such as NF$\kappa B$. Activated macrophages/DCs ferry $\beta$-cells antigens specifically to pancreatic lymph nodes, where they trigger reactive $T$ cells through synapse formation and secretion of proinflammatory cytokines and more ROS. ROS generation, therefore, is pivotal in formulating both innate and adaptive immune responses accountable for islet cell autoimmunity (Delmastro \& Piganelli, 2011).

Ethanolic extract of Balinese grapes may help prevent pancreatic $\beta$-cells damage since grapes are a source of antioxidants with high polyphenol content. Flavonoid is one of polyphenol which abundantly contains in grapes. Effects of flavonoids against ROS occurs through two mechanisms: by increasing endogenous antioxidant and direct scavenger activity. Increased endogenous antioxidant by flavonoids has been proven in vitro studies through an increased Nrf2 transcription factor that increases the expression of proteins HO-1 (Velagapudi, ElBakoush, \& Olajide, 2018). Flavonoids can activate the ERK, JNK, and p38 then activates Nrf2 resulting in increased gene expression of endogenous antioxidants (Mansuri, Parihar, Solanki, \& Parihar, 2014).

Flavonoids have been known as a natural antioxidant that protects pancreatic $\beta$-cells from free radical damage. Furthermore, previous studies reported that besides protecting pancreatic $\beta$ cells from damage by oxidative stress, it also triggers the proliferation of $\beta$-cells within pancreatic islet (Pinent et al., 2008). Flavonoids play a role in controlling blood glucose by increasing insulin secretion through elevating metabolism of $\mathrm{Ca}^{2+}$ and regenerate pancreatic $\beta$-cells (Dias Soares, Pereira Leal, Silva, Almeida, \& de Oliveira, 2017; Ghorbani, Rashidi, \& Shafiee-Nick, 2019). Through interaction with the ATP-sensitive $K$ channels in the membrane of beta cells causing membrane depolarization and this situation will open Sodium gate channels. The opening of sodium gate channels caused $\mathrm{Ca}^{2+}$ entering beta cells and then stimulate granules containing insulin secretion (Zhong \& Jiang, 2019).

The content of resveratrol in Balinese grapes can effectively reduce oxidative damage to the pancreas, and thus can protect pancreatic $\beta$-cell function (Lee et al., 2012). Quercetin is a flavonoid polyphenol naturally found in a wide variety of plant-based food sources including grape, which has anti-diabetic activity. Studies showed quercetin can protect the function and keep the number of pancreatic $\beta$-cells from oxidative damage induced by $\mathrm{H}_{2} \mathrm{O}_{2}$ (Youl et al., 2010). This effect is mediated by phosphorylation of extracellular signal-regulated kinase (ERK-1/ERK-2) (Maurya \& Vinayak, 2016). Quercetin also reduces the concentration of thiobarbituric acid and lipid hydroperoxide in the pancreas and increase the activity of antioxidant enzymes (Boots, Drent, de Boer, Bast, \& Haenen, 2011). These results indicate that the antioxidative activity of quercetin may protect pancreatic beta-cells from damage by 
reducing oxidative stress caused by various exogenous and endogenous sources such as excessive physical training.

\section{Total Creatine Kinase Level}

The mean level of total creatine kinase of the control group (PO) was $289.56 \pm 18.82 \mathrm{mU} / \mathrm{mL}$, and the treatment group (P1) was $243.56 \pm 19.30 \mathrm{mU} / \mathrm{mL}(\mathrm{p}<0,001$; Table 1). Creatine kinase (CK) is an enzyme typically found in muscle. CK activity as measured by muscle biopsy showed a different level before and after training (Brancaccio, Maffulli, \& Limongelli, 2007). In addition to pancreatic $\beta$-cells damage, excessive physical training can also result in damage to skeletal muscle. Increased production of ROS that occurs during physical exercise can cause oxidative damage to muscle, liver, blood and other tissues, as proven by increasing CK in this study. Excessive physical training has proved contribute to an increase in oxygen consumption in skeletal muscle (Jones et al., 2017), an increase in lipid peroxidation, and inhibition of mitochondrial enzymes such as citrate synthase and malate dehydrogenase (Zoppi \& Macedo, 2007). In this study, the level of total CK in P1 group is significantly lower than those observed in PO group, suggesting that the ethanolic extract of Balinese grape reduced the muscle damage caused by excessive physical exercise.

Serum CK levels can increase due to damaged muscle tissue as a consequence of the training with the high frequency and intensity level. This may be a result of metabolic processes and mechanical causes. Metabolic processes underlying muscle damage due to excessive physical training is a decrease in membrane resistance which was followed by an increase in intracellular free calcium ions, which then induce the activation of potassium channels. Other mechanisms that cause local tissue damage muscle degeneration sarcomere Z-disk. CK is a good marker for muscle necrosis due to metabolic or mechanical processes, which will increase along with the increased sburden of physical activity (Brancaccio et al., 2007).

\section{Conclusion}

Based on the results of this study, it can be concluded that the administration of $25 \mathrm{~g} / \mathrm{kg} . \mathrm{BW}$ ethanolic extract of Balinese grapes can prevent the pancreatic $\beta$-cells and skeletal muscle cells damage on overtraining-induced wistar rat (Rattus norvegicus). Further study is required to dissect the molecular mechanism underlying the phytochemical compound-specific mechanism on anti-oxidative damage of Balinese grapes extract.

\section{Refferences}

Baird, M. F., Graham, S. M., Baker, J. S., \& Bickerstaff, G. F. (2012). Creatine-Kinase- and Exercise-Related Muscle Damage Implications for Muscle Performance and Recovery. Journal of Nutrition and Metabolism, 2012, 1-13. https://doi.org/10.1155/2012/960363

Boots, A. W., Drent, M., de Boer, V. C. J., Bast, A., \& Haenen, G. R. M. M. (2011). Quercetin reduces markers of oxidative stress and inflammation in sarcoidosis. Clinical Nutrition, 30(4), 506-512. https://doi.org/10.1016/j.clnu.2011.01.010

Brancaccio, P., Maffulli, N., \& Limongelli, F. M. (2007). Creatine kinase monitoring in sport medicine. British Medical Bulletin, 81-82(1), 209-230. https://doi.org/10.1093/bmb/ldm014

Delmastro, M. M., \& Piganelli, J. D. (2011). Oxidative Stress and Redox Modulation Potential in Type 1 Diabetes. Clinical and Developmental Immunology, 2011, 1-15. https://doi.org/10.1155/2011/593863

Dias Soares, J., Pereira Leal, A. B., Silva, J., Almeida, J. G. S., \& de Oliveira, H. (2017). Influence of flavonoids on mechanism of modulation of insulin secretion. Pharmacognosy Magazine, 
13(52), 639. https://doi.org/10.4103/pm.pm_87_17

Doshi, P., Adsule, P., Banerjee, K., \& Oulkar, D. (2015). Phenolic compounds, antioxidant activity and insulinotropic effect of extracts prepared from grape (Vitis vinifera L) byproducts. Journal of Food Science and Technology, 52(1), 181-190. https://doi.org/10.1007/s13197-013-0991-1

Ghorbani, A., Rashidi, R., \& Shafiee-Nick, R. (2019). Flavonoids for preserving pancreatic beta cell survival and function: A mechanistic review. Biomedicine \& Pharmacotherapy, 111, 947-957. https://doi.org/10.1016/j.biopha.2018.12.127

González-Montero, J., Brito, R., Gajardo, A. I., \& Rodrigo, R. (2018). Myocardial reperfusion injury and oxidative stress: Therapeutic opportunities. World Journal of Cardiology, 10(9), 74-86. https://doi.org/10.4330/wjc.v10.i9.74

Gulati, M., Pandey, D. K., Arnsdorf, M. F., Lauderdale, D. S., Thisted, R. A., Wicklund, R. H., ... Black, H. R. (2003). Exercise Capacity and the Risk of Death in Women. Circulation, 108(13), 1554-1559. https://doi.org/10.1161/01.CIR.0000091080.57509.E9

Han, Y., Wu, J., \& Wang, C. (2019). Modulatory effects of miracle fruit ethanolic extracts on glucose uptake through the insulin signaling pathway in $\mathrm{C} 2 \mathrm{C} 12$ mouse myotubes cells. Food Science \& Nutrition, 7(3), 1035-1042. https://doi.org/10.1002/fsn3.935

Haryanto, P., Pangkahila, A., Aman, I. G. M., \& Siswanto, F. M. (2019). Pengaruh Latihan Fisik Intensitas Sedang terhadap Jumlah Reseptor Insulin di Jaringan Lemak Tikus Jantan Obesitas The Influence of Moderate Intensity Exercise to The Level of Insulin Receptors on Adipose Tissue of Obese Male Rats, 7(1), 23-27. https://doi.org/10.23886/ejki.7.9587.Abstrak

Jones, S., D'Silva, A., Bhuva, A., Lloyd, G., Manisty, C., Moon, J. C., ... Hughes, A. D. (2017). Improved Exercise-Related Skeletal Muscle Oxygen Consumption Following Uptake of Endurance Training Measured Using Near-Infrared Spectroscopy. Frontiers in Physiology, 8. https://doi.org/10.3389/fphys.2017.01018

Kartiko, B. H., \& Siswanto, F. M. (2015). Hormon dalam konsep Anti Aging Medicine. Jurnal Virgin, 1(2), 108-122.

Kartiko, B. H., \& Siswanto, F. M. (2018). Overtraining elevates serum protease level, increases renal p16INK4 $\alpha$ gene expression and induces apoptosis in rat kidney. Sport Sciences for Health, 14(2), 1-7. https://doi.org/10.1007/s11332-018-0433-6

Khoo, H. E., Azlan, A., Tang, S. T., \& Lim, S. M. (2017). Anthocyanidins and anthocyanins: colored pigments as food, pharmaceutical ingredients, and the potential health benefits. $\begin{array}{llll}\text { Food \& Nutrition } & 1361779 .\end{array}$ https://doi.org/10.1080/16546628.2017.1361779

Lee, Y.-E., Kim, J.-W., Lee, E.-M., Ahn, Y.-B., Song, K.-H., Yoon, K.-H., ... Ko, S.-H. (2012). Chronic Resveratrol Treatment Protects Pancreatic Islets against Oxidative Stress in $\mathrm{db} / \mathrm{db}$ Mice. PLOS ONE, 7(11), e50412. https://doi.org/10.1371/journal.pone.0050412

Mansuri, M. L., Parihar, P., Solanki, I., \& Parihar, M. S. (2014). Flavonoids in modulation of cell survival signalling pathways. Genes \& Nutrition, 9(3), 400. https://doi.org/10.1007/s12263-014-0400-z

Maurya, A. K., \& Vinayak, M. (2016). PI-103 and Quercetin Attenuate PI3K-AKT Signaling Pathway in T-Cell Lymphoma Exposed to Hydrogen Peroxide. PLOS ONE, 11(8), e0160686. https://doi.org/10.1371/journal.pone.0160686

Nimse, S. B., \& Pal, D. (2015). Free radicals, natural antioxidants, and their reaction mechanisms. RSC Advances, 5(35), 27986-28006. https://doi.org/10.1039/C4RA13315C

Nyandra, M., Kartiko, B. H., Arunngam, P., Pangkahila, A., \& Siswanto, F. M. (2018). Overtraining Induces Oxidative Stress Mediated Renal Damage in Male Wistar Rats. Transylvanian Review, 26(28), 7659-7666.

Pangkahila, E., Linawati, N. M., Sugiritama, I. W., \& Siswanto, F. M. (2019). Pelatihan Fisik Berlebih Meningkatkan Indeks Apoptosis pada Hepatosit Tikus (Rattus norvegicus) Wistar Jantan. Jurnal Biomedik, 11(3), 144-149. 
Pereira, B. C., Pauli, J. R., Antunes, L. M. G., de Freitas, E. C., de Almeida, M. R., de Paula Venâncio, V., ... da Silva, A. S. R. (2013). Overtraining is associated with DNA damage in blood and skeletal muscle cells of Swiss mice. BMC Physiology, 13, 11. https://doi.org/10.1186/1472-6793-13-11

Pinent, M., Castell, A., Baiges, I., Montagut, G., Arola, L., \& Ardévol, A. (2008). Bioactivity of Flavonoids on Insulin-Secreting Cells. Comprehensive Reviews in Food Science and Food Safety, 7(4), 299-308. https://doi.org/10.1111/j.1541-4337.2008.00048.x

Siswanto, F. M., \& Pangkahila, A. (2014). Pelatihan Fisik Seimbang Meningkatkan Aktivitas Stem Cell Endogen Untuk Anti Penuaan. Sport and Fitness Journal, 2(1), 1-9.

Siswanto, F. M., \& Pangkahila, E. A. (2015). Pola Hidup Tidak Teratur dan Aktivitas Fisik Berlebih Menurunkan Kemampuan Aktivitas Seksual. Sport and Fitness Journal, 3(1), 5969.

Siswanto, F. M., Yenniastuti, B., Putra, T. A., \& Kardena, I. M. (2015). Aktivitas Fisik Maksimal Akut (Acute Overtraining) Menyebabkan Kerusakan Sel $\beta$ Pankreas Mencit. Jurnal Biomedik, 7(2), 125-130.

Velagapudi, R., El-Bakoush, A., \& Olajide, O. A. (2018). Activation of Nrf2 Pathway Contributes to Neuroprotection by the Dietary Flavonoid Tiliroside. Molecular Neurobiology, 55(10), 8103-8123. https://doi.org/10.1007/s12035-018-0975-2

Wasfy, M. M., Hutter, A. M., \& Weiner, R. B. (2016). Sudden Cardiac Death in Athletes. Methodist DeBakey Cardiovascular Journal, 12(2), 76-80. https://doi.org/10.14797/mdcj12-2-76

Widhiantara, I. G., Arunngam, P., \& Siswanto, F. M. (2018). Ethanolic Extract of Caesalpinia bonducella $\mathrm{f}$. Seed Ameliorates Diabetes Phenotype of Streptozotocin- NicotinamideInduced Type 2 Diabetes Rat. Biomedical and Pharmacology Journal, 11(2), 1127-1133. https://doi.org/10.13005/bpj/1473

Yang, L., Xian, D., Xiong, X., Lai, R., Song, J., \& Zhong, J. (2018). Proanthocyanidins against Oxidative Stress: From Molecular Mechanisms to Clinical Applications. BioMed Research International, 2018, 1-11. https://doi.org/10.1155/2018/8584136

Youl, E., Bardy, G., Magous, R., Cros, G., Sejalon, F., Virsolvy, A., ... Oiry, C. (2010). Quercetin potentiates insulin secretion and protects INS-1 pancreatic -cells against oxidative damage via the ERK1/2 pathway. British Journal of Pharmacology, 161(4), 799-814. https://doi.org/10.1111/j.1476-5381.2010.00910.x

Zenitalia, Pangkahila, A., Pangkahila, W., \& Siswanto, F. M. (2018). Pelatihan Fisik Berlebih Menurunkan Jumlah Hematopoietic Stem Cells (HSCs) Dibandingkan Pelatihan Fisik Seimbang pada Tikus (Rattus norvegicus) Wistar Jantan. Jurnal Biomedik, 10(1), 16-23.

Zhong, F., \& Jiang, Y. (2019). Endogenous Pancreatic $\beta$ Cell Regeneration: A Potential Strategy for the Recovery of $\beta$ Cell Deficiency in Diabetes. Frontiers in Endocrinology, 10. https://doi.org/10.3389/fendo.2019.00101

Zoppi, C. C., \& Macedo, D. V. (2007). Overreaching-induced oxidative stress, enhanced HSP72 expression, antioxidant and oxidative enzymes downregulation. Scandinavian Journal of Medicine \& Science in Sports, 18(1), 67-76. https://doi.org/10.1111/j.16000838.2006.00630.x 